\title{
Mapping Gerasa: a new and open data map of the site
}

Achim Lichtenberger ${ }^{1}$, Rubina Raja ${ }^{2, *} \&$ David Stott $^{3}$

This article presents a new and accurate map of Gerasa/Jerash, an important site located in modern northern Jordan, which displays urban development spread across more than two millennia.

Keywords: Jordan, Gerasa, lidar, orthophotography, map

The Decapolis city of Gerasa has been the subject of continuous research since it was rediscovered by the German scholar Ulrich Jasper Seetzen in 1806 (Kruse et al. 1854: 388-90). The Decapolis_-nominally 10 cities_-were located in the heavily urbanised region of what is today northern Jordan and southern Syria, with one city, Scythopolis, situated on the west bank of the River Jordan in modern Israel and Hippos East of Lake Tiberias. After the rediscovery, Gerasa was visited by numerous travellers in the nineteenth and twentieth centuries (Stott et al. 2018: 1; Lichtenberger \& Raja in press). The city, which covers more than 80ha, holds numerous monumental buildings that have been visible since antiquity. Although several maps have been produced of the site, none, however, have aimed for complete accuracy. Seetzen produced the first map of the site, published in 1854. Later travellers also made maps, largely recording the same monuments (Burckhardt 1822; Boyer 2016; Raja in press). Gottlieb Schumacher visited the site several times and his map of the site was published in 1902 (Schumacher 1902).

In 1938, the Anglo-American expedition to Gerasa published a new map in the final publication of the excavations (Kraeling 1938; Fisher 1938: pl. I). For decades, this was the map used in scholarship. Browning (1982: 83, map 3), in his book on the archaeology and history of the site, published a reduced map. When the Jerash Archaeological Project was initiated in the 1970s by the Department of Antiquities of Jordan with the support of UNESCO, another map was published in the resulting volume (Pillen 1986). In 2001, Braun et al. (2001: 434) published another updated map, which included monuments that have been lost over time to modern development. In 2011, Lepaon (2011: 416) published an updated map of the site, collating information from the previous maps. This incorporated spatial inaccuracies (Stott et al. 2018: 2), however, and did not include a legend, despite a numbered list of monuments being included in the article. All these maps were made using terrestrial data,

1 Institut für Klassische Archäologie und Christliche Archäologie/Archäologisches Museum, Domplatz 20-22, 48143 Münster, Germany

2 Department of Classical Studies and Centre for Urban Network Evolutions (UrbNet), Moesgård Allé 20, 8270 Højbjerg, Denmark

3 Unit of Archaeological Information Technology, Moesgaard Museum, 8270 Højbjerg, Denmark

* Author for correspondence (Email: rubina.raja@cas.au.dk)

(C) Antiquity Publications Ltd, 2019

ANTIQUITY 93 367, e7 (2019): 1-7

https://doi.org/10.15184/aqy.2019.9 


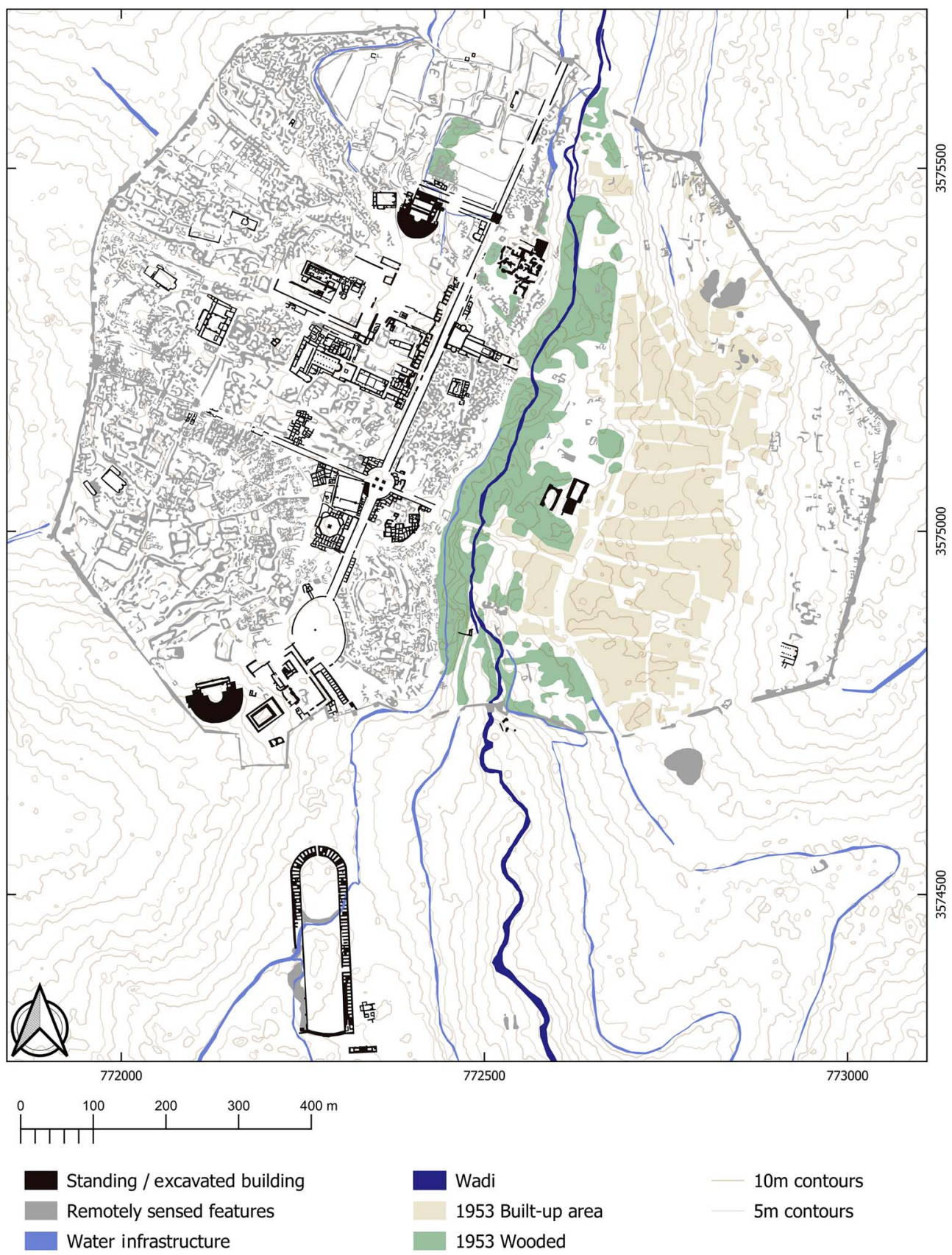

Figure 1. Map of potential archaeological features derived from airborne lidar and archival photography. A large number of previously recorded and new features were recorded in the better-preserved part of the city to the west of the wadi (map (C) Danish-German Jerash Northwest Quarter Project: https:I/doi.org/10.6084/m9.figshare. 7609859.v1).

(C) Antiquity Publications Ltd, 2019 

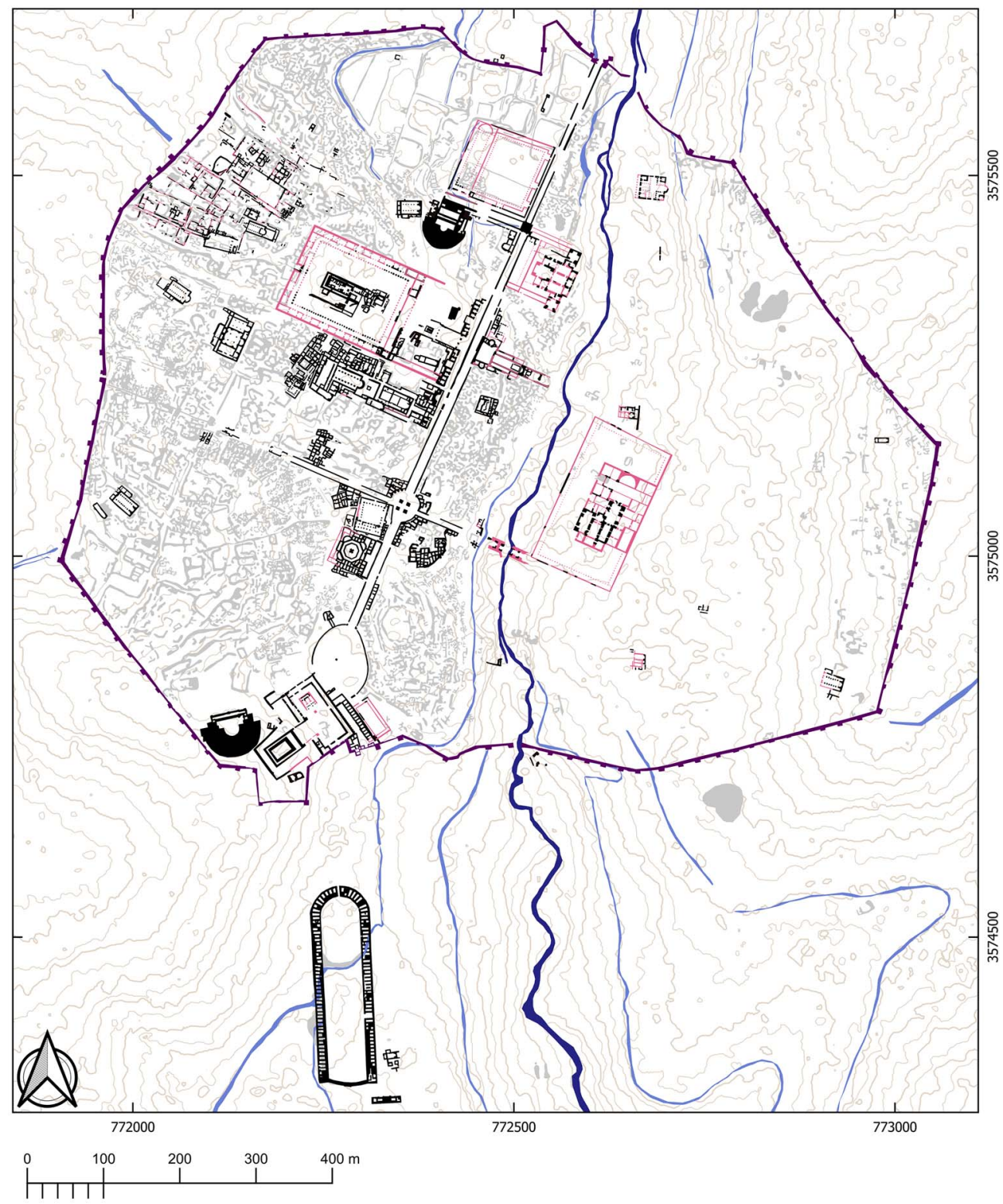

Building foundation

Conjectural building

City wall (after Kraeling 1938)
Water infrastructure

Remotely sensed features

Wadi

Figure 2. Synthesis of remotely sensed features and existing mapping from previous studies. Hypothetical building elements (after Lepaon 2011; Lichtenberger \& Raja 2017) are highlighted in pink. Most of the buildings on the eastern side of the valley are no longer extant (map (C) Danish-German Jerash Northwest Quarter Project: https://doi. org/10.6084/m9.figshare.7609859.v1). 

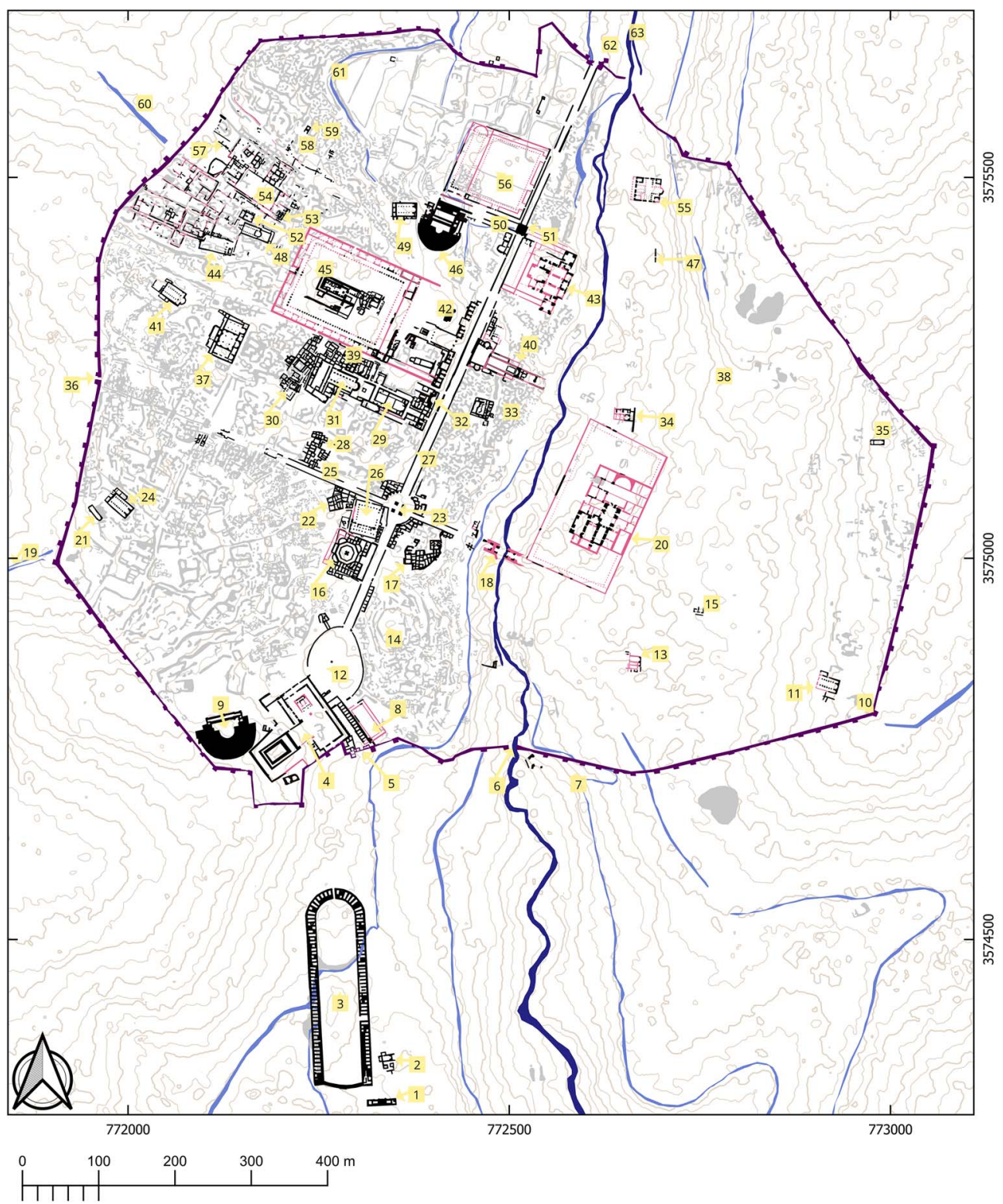

Building foundation

Conjectural building

City wall (after Kraeling 1938)

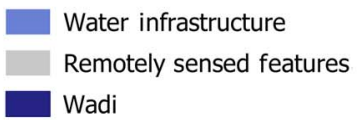

$10 \mathrm{~m}$ contours

$5 \mathrm{~m}$ contours

Figure 3. As Figure 2, with points of interest highlighted (see Table 1) (map (C) Danish-German Jerash Northwest Quarter Project: https://doi.org/10.6084/m9.fgshare.7609859.v1).

(C) Antiquity Publications Ltd, 2019 
Table 1. Jerash map-legend.

1 Extramural arch ('Hadrian's Arch')

2 Church of Bishop Marianos

3 Hippodrome

4 Sanctuary of Zeus Olympios

5 South Gate

6 Water Gate

7 City walls

8 Shops and structures along the South Gate street

9 South Theatre

10 South-East Gate (blocked)

11 Procopius Church

12 'Oval Piazza'

13 Roman house or church (after Schumacher 1902)

14 'Camp Hill' (location of modern museum)

15 Byzantine villa (after Seigne \& Zubi 1997)

16 Agora ('Macellum')

17 Area of the House of the Blues

18 South Bridge

19 Possible South-West Aqueduct

20 East Baths

21 Mortuary Church

22 Late Antique and Early Islamic structures

23 South Tetrapylon

24 Church of Sts Peter and Paul

25 Side street ('South Decumanus')

26 Mosque

27 Main Street ('cardo')

28 Early Islamic domestic quarter

29 Cathedral complex

30 'Temple C' (after Fisher 1938: pl. I)

31 Church of St Theodore and Fountain Court

32 Nymphaion

33 Buildings west of the Wadi

34 Small Eastern Baths

35 Chapel of Elia, Mary and Soreg

36 South-West Gate

37 Churches of Sts George, John, Cosmas and Damian

38 Approximate location of 'House of the Poets and Muses'

39 Ecclesiastic complexes and Baths of Placcus

40 Propylaea Church

41 Church of Bishop Genesius

42 Ottoman House

43 West Baths

44 Large rock-cut cistern

45 Sanctuary of Artemis

46 North Theatre 
Table 1. (Continued)

Jerash map-legend.

47 Spring (Ain Karawan)

48 Synagogue/Church of the Electi Iustiniani

49 Church of Bishop Isaiah

50 Side street ('North Decumanus')

51 North Tetrapylon

52 Hall of the Electi Iustiniani

53 Umayyad houses

54 Middle Islamic hamlet (and large courtyard)

55 Church of the Prophets, Apostles and Martyrs

56 Large open area ('forum') and basilica

57 Roman edifice and cistern

58 Middle Islamic structures

59 Circassian house

60 North-West Aqueduct

61 Early modern water channel

62 North Gate

63 Chrysorrhoas/Wadi Jerash

compiled partly by the cartographers themselves and partly from earlier data, leading to a propagation of errors from previous maps.

Since 2011, the Danish-German Jerash Northwest Quarter Project has been producing maps of the area behind the Sanctuary of Artemis through survey and excavation (Lichtenberger \& Raja 2015, 2017). In 2016, lidar data and orthophotography were acquired through the Royal Jordanian Geographic Society. This allowed for the precise topographic measurement of the city and its surroundings, and provided an accurate basemap for co-registering historical aerial photography. This resulted in the mapping of a large number of archaeological features (Stott et al. 2018).

During the process of combining the existing mapping with data from the aerial surveys, it became clear that an updated map of the city was required (Stott $e t$ al. 2018: 2). The authors used the 2016 data as the basis to integrate the existing mapping into a common spatial framework. Numerous nineteenth-century travellers described the site, and archaeological fieldwork has been ongoing for over a century. Hence, there is little consensus on the names of the city's monuments. In particular, early excavators chose Latin names for monuments-inappropriate for a Greek city in the Roman East. The new map has taken a pragmatic approach. Whenever possible, we use the appropriate emic terminology and names for the monuments, but when they already have well-established 'nicknames', we have respected these in recognition of the long history of the city and its historiography.

The new map provides a more accurate spatial understanding of the city, and it will prove valuable to archaeologists, cultural heritage managers and visitors (Figures 1-3). In this spirit, the map is released under a Creative Commons licence, permitting re-use and reworking of 
the map. This is important as our understanding is continually evolving, and this map will need to be updated as we learn more. Sharing knowledge in this way enables better collaboration, reduces duplication of effort and conforms to the international FAIR Guiding Principles for data management and data sharing (Wilkinson et al. 2016; https://dg.dk/ forskningsaktiviteter/god-forskningspraksis/open-access-politik/).

\section{Acknowledgements}

The authors thank the funding bodies of the project: The Carlsberg Foundation, the Danish National Research Foundation (grant number: 119), Deutsche Forschungsgemeinschaft, Deutscher Palästina-Verein, the EliteForsk initiative of the Danish Ministry of Higher Education and Science, and H.P. Hjerl Hansens Mindefondet for Dansk Palæstinaforskning.

\section{References}

Boyer, D. 2016. The ruins of Gerasa in 1816-1819: an analysis of the plan and drawing archives of William John Bankes and Charles Barry. Studies in the History and Archaeology of Jordan 12: 279-300.

Braun, J.-P. et al. 2001. The town plan of Gerasa in AD 2000: a revisited edition. Annual of the Department of Antiquities of Jordan 45: 433-36.

Browning, I. 1982. Jerash and the Decapolis. London: Chatto \& Windus.

Burckhardt, J.L. 1822. Travels in Syria and the Holy Land. London: Murray.

Fisher, C.S. 1938. Description of the site, in C.H. Kraeling (ed.) Gerasa. City of the Decapolis: 11-25. New Haven (CT): American Schools of Oriental Research.

Kraeling, C.H. 1938. Gerasa. City of the Decapolis. New Haven (CT): American Schools of Oriental Research.

Kruse, F., Dr Hinrichs \& F.G. Müller. 1854. Ulrich Jasper Seetzen's Reisen durch Syrien, Palästina, Phönicien, die Transjordan-Länder, Arabia Petraea und Unter-Aegypten, I. Berlin: Reimer.

LepaOn, T. 2011. Un nouveau plan pour Jarash/ Gerasa (Jordanie). Annual of the Department of Antiquities of Jordan 55: 409-20.

Lichtenberger, A. \& R. Raja. 2015. New archaeological research in the northwest quarter of Jerash and its implications for the urban development of Roman Gerasa. American Journal of Archaeology 119: 483-500.

https://doi.org/10.3764/aja.119.4.0483
Lichtenberger, A. \& R. Raja. (ed.). 2017. Gerasal Jerash: from the urban periphery. Aarhus: Fællestrykkeriet AUTRYK.

Lichtenberger, A. \& R. Raja. In press. By the Golden River. Gerasa through the eyes of $19^{\text {th }}$ and early $20^{\text {th }}$ century visitors. Turnhout: Brepols.

Pillen, R.E. 1986. Jerash plan, in F. Zayadine (ed.) Jerash Archaeological Project 1981-1983 (volume 1). Amman: Department of Antiquities.

RAJA, R. In press. Entry and commentary on Catherwood, in A. Lichtenberger \& R. Raja By the Golden River. Gerasa through the eyes of $19^{\text {th }}$ and early $20^{\text {th }}$ century visitors. Turnhout: Brepols.

Schumacher, G. 1902. Dscherasch. Zeitschrift des Deutschen Palästina-Vereins 25: 109-77.

Seigne, J. \& I. Zubi. 1997. Roman villa, in C. Castel, M. al-Maqdissi \& F. Villeneuve (ed.) Les maisons dans la Syrie antique du IIIe millénaire aux débuts de l'Islam (Pratique et Représentations de L'espace Domestique: Actes du Colloque International, Damas, 27-30 Juin 1992). Beirut: IFAPO.

Stott, D., S.M. Kristiansen, A. Lichtenberger $\&$ R. RajA. 2018. Mapping an ancient city with a century of remotely sensed data. Proceedings of the National Academy of Sciences of the USA 115(24). https://doi.org/10.1073/pnas.1721509115

WiLkinson, M.D. et al. 2016. Comment: The FAIR Guiding Principles for scientific data management and stewardship. Nature Scientific Data 3. 